\title{
Growth performance and proximate composition of grey mullet Liza parsia at different salinities
}

\author{
JOYANTA BIR ${ }^{*}$, RIMU DAS, MD RONY GOLDER, SHIKDER SAIFUL ISLAM ${ }^{\mathbf{1}}$, \\ PRIANKA PAUL ${ }^{2}$, MD. IMRAN NOOR, MD ROFIQUL ISLAM, SAROWER E- \\ MAHFUJ $^{1}$, ALOKESH KUMAR GHOSH ${ }^{3}$ AND KHANDAKER ANISUL HUQ \\ Fisheries and Marine Resources Technology Discipline, Khulna University, Khulna 9208, Bangladesh \\ ${ }^{1}$ Institute for Marine and Antarctic Studies, University of Tasmania, Australia \\ ${ }^{2}$ Department of Fisheries and Marine Bioscience, Jashore University of Science and Technology, Jashore \\ ${ }^{3}$ Department of Biology, Katholieke Universiteit Leuven, Belgium \\ *Email: joy@fmrt.ku.ac.bd
}

\begin{abstract}
The study was conducted to evaluate growth, survivability, and proximate composition of Liza parsia at different salinities to adopt as a potential aquaculture species in salinity intruded coastal areas of Bangladesh. The experiment was carried out at laboratory conditions in rectangular tanks $(25 \mathrm{~L})$ with five different salinities viz. $0,5,10,15$ and 20 ppt correspondingly considered as T1(control), T2, T3, T4 and T5. Fingerlings were collected from the Pashur river and stocked at 10 individual/25L tank. After 90 days of culture period, growth was found significantly different among the treatments. Average weight gain was highest inT2 (1.76 \pm 0.19$)$ and lowest inT5 $(0.91 \pm 0.15)$. Interestingly survival rate was found $100(\%)$ in all treatment. Specific growth rate was $0.829 \pm 0.10,1.162 \pm 0.14,0.744 \pm 0.2,0.736 \pm 0.10$ and $0.605 \pm 0.15$ respectively in T1, T2, T3, T4 and T5. Average daily gain was found higher in T1 $(0.059 \pm 0.006 \mathrm{~g} / \mathrm{d})$, compared to other treatment. The average food conversion ratios were $0.78 \pm 0.06,1 \pm 0.00,0.69 \pm 0.06$, $0.78 \pm 0.22$ and $1.035 \pm 0.25$ in $\mathrm{T} 1, \mathrm{~T} 2, \mathrm{~T} 3, \mathrm{~T} 4$ and $\mathrm{T} 5$ in five tanks, respectively. Better water quality parameters were observed in $\mathrm{T} 2$. The temperature ranged from $28-30.3^{\circ} \mathrm{C}, \mathrm{pH}$ from $7.21-7.64$, DO from $5.01-5.68 \mathrm{ppm}$, hardness from $184.55-237.65 \mathrm{mg} / \mathrm{l}$ and total ammonia nitrogen (TAN) ranged from $0.52-0.85$ $\mathrm{mg} / \mathrm{l}$. No significant change was observed in the proximate composition of fish reared at different salinities. Finally, it could be concluded that $L$. parsia can tolerate a wide range of salinity and can be cultured even in freshwater, thus might be a potential species for coastal aquaculture.
\end{abstract}

Keywords: Liza parsia, Salinity, Proximate composition

\section{Introduction}

Bangladesh is the largest deltaic country in the world which is very much vulnerable to climate change such as cyclone and storm surges, variations in temperature and rainfall, drought, and salinity intrusion (Rabbani et al. 2018). Salinity intrusion is an alarming problem for freshwater aquaculture and severely affecting the life and livelihood in the southern coastal areas of Bangladesh (Mahmuduzzaman et al. 2014, Rabbani et al. 2018). The salinity affected area in Bangladesh was 102 million hectares in 2000 which increased to 05.6 million hectares in the year of 2009. Traditionally Shrimp, prawn, Crab and freshwater aquaculture are widely practiced in the coastal belt of this country because of suitable culture environment (Azad et al. 2019). But this culture trend dramatically changed in last few decades because of saline water intrusion and sea level rise which causes highly vulnerable situation in freshwater aquaculture. Increased salinity affects the growth of standing crops and affects overall fish production (Mahmuduzzaman et al. 2014). Too many freshwater species i.e. carps, small indigenous species (SIS) etc. culture are now really vulnerable in this increasing saline water intruded 


\section{GROWTH AND PROXIMATE COMPOSITION OF GREY MULLET}

region (Ghosh et al. 2016, DoF 2018). In these circumstances coastal aquaculture demands to introduce new euryhaline fish species that can adapt to a wide range of salinities.

Gold spot mullet (Liza parsia) might be a good candidate species in these salinities intruded coastal belt because of its euryhaline nature and huge market demands. In Bangladesh, this species has great potentiality and sometimes wildly cultured withshrimp and prawn (Bir et al. 2016, Islam et al. 2017). L. parsia belongs to the family Mugillidae is a catadromous fish, found mostly in soft-bottom habitats, capable to tolerate an extensive range of temperature and salinity and widely distributed in the coastal waters of tropical and sub-tropical regions (Panda et al. 2018). This fish is very delicious because of its high nutritive value, excellent flesh quality and high market demand as well as, which are considered to be important for culture in coastal areas (Bir et al. 2016, Dayal et al. 2017, Islam et al. 2017). Mullets are generally considered as herbivorous, omnivorous, plankton feeders, or even micro crustacean predators (Trivedi et al. 2015, Mondal et al. 2016, Bir et al. 2016). Commercially this species being cultured in many developed countries in their sallow coastal waters, estuary and mangrove swamps (Dayal et al. 2017, Panda et al. 2018). The adult and juvenile are hardy, euryhaline, eurythermal and not competitive for food (Islam et al. 2017). Juveniles often occur in shrimp culture farms and mangrove swamps that make the most favorable species in Bangladesh as well as in the Southeast Asia and many parts of central and South America. The present study focuses on growth, survivability, proximate composition and aquaculture prospects in to adopt as a candidate aquaculture species in salinity intruded coastal area.

\section{Materials and Methods}

Experiment set up: The experiment was conducted in rectangular shape fiber-reinforced plastic (FRP) tanks (25L, $49.53 \times 30.48 \times 34.29 \mathrm{~cm})$ at fish wet lab and fish nutrition lab of Fisheries and Marine Resources Technology Discipline, Khulna University. Experiment was designed with five different salinities expressed as T2 (5 ppt), T3 (10 ppt), T4 (15 ppt) and T5 (20 ppt) with a control group T1 of zero salinities. The experiment period was 90 days from July 2019 to September 2019 . The stocking density was (10 individuals/25L tank) equal to each treatment.

Sample collection and tank salinity management: Fingerlings were collected from the wild source, Pashur River and acclimatized with de-chlorinated brackish water for ten days before treated with salt solutions. Saline water was made by mixing sea salt with lab water while control was normal tube well water. Tank water salinization was done by sea salt and desired salinity level $(5,10,15$ and $20 \mathrm{ppt})$ was maintained by using $S_{1} V_{1}=S_{2} V_{2}$ dilution equation. All the mentioned salinity levels were maintained throughout the experimental period by regular applications of sea salt following its measurement by salinity meter (Condi 330i, WTW 82362 Weilheim Germany) to ensure the required salinity level on daily basis. Uninterrupted aeration was provided throughout the experimental period.

Feed and feeding management: Commercial feed containing 35\% crude protein, $7 \%$ crude fat, $25 \%$ carbohydrate, $12 \%$ moisture, $4 \%$ fiber, $17 \%$ ash, $3.2 \%$ calcium and $1.5 \%$ phosphorus was given twice in a day at 10:00 hours and 17:00 hours at 10\% of the total body weight for first month and $8 \%$ of body weight for last two months. 
JOYANTA BIR et al.

Aeration and water exchange system: Continuous aeration was provided through small aquarium aerator (Aquarium Air Pump, model SOBO SB-248A) for nonstop supply of oxygen. Everyday $20 \%$ water was exchanged for maintaining the water quality and removal of uneaten feed from the tank.

Measurement of growth parameters: Sampling was done weekly, and all specimens (10/Tank) were taken from each tank for the measurement of length $(\mathrm{cm})$ and weight $(\mathrm{g})$. At the end of the experiment, all the survived fish were harvested to determine growth performance and survival rate and proximate composition analysis. The following formulae were used to evaluate different parameters.

i. Average individual weight gain (WG) $=W t-W 0$. Where $W t$ is the final body weight and $\mathrm{W}_{0}$ is the initial body weight (in grams)

ii. Specific growth rate $(\mathrm{SGR})=\frac{\left\{\ln \left(W_{t}\right)-\ln \left(W_{0}\right)\right\}}{t} \times 100$, where $\mathrm{t}$ is the duration of the experiment in days, $\mathrm{Wt}$ is the final average individual body weight and $\mathrm{W}_{0}$ is the initial average individual body weight (in \% BW/ day)

iii. Feed conversion ratio $(\mathrm{FCR})=\frac{T F G}{T W G}$, Where TFG $=$ Total feed given (dry matter basis) and TWG $=$ Total weight gained

iv. The relationship between total length (TL) and total weight (TW) of L parsia was calculated using power function.

$T W=a T L^{b}$, Where TW Total weight $(\mathrm{g}) \mathrm{TL}$ Total length $(\mathrm{cm})$ a Intercept of the regression line $\mathrm{b}$ Slope of the regression line

Proximate composition analysis: The proximate composition such as protein, lipid, ash and moisture contents were measured at the time of stocking and after final harvesting in order to compare the values before and after the salt treatment. Protein was determined by measuring the percentage of nitrogen $(\% \mathrm{~N})$ into the sample multiplied with conversion factor (6.25) using micro Kjeldahl method. The percentage of gross portentous nitrogen $(\% \mathrm{~N})$ was calculated following (Lim 1987).

Water quality parameters measurement: Water samples were taken at 7 days interval from each treatment and control. Salinity was measured by a Refractometer (ATAGO CO. LTD, Japan, Master- T 2312), temperature was measured by using a Digital Thermometer (DIGITAL THERMOME-TER, made in China). $\mathrm{pH}$ was measured by using a $\mathrm{pH}$ meter (HACH, Sension 3, USA). Dissolved oxygen was measured by a DO meter (PDO-519, made in Taiwan, Lutron) and Total Ammonia nitrogen (TAN) measured by following Nessler method. Titrimetric method was used to determine alkalinity and hardness.

Statistical analysis: All the data were presented as mean \pm SE of the mean and were tested for homogeneity of variance using Leven's test. Aone-way analysis of variance (ANOVA) was applied to determine the differences in growth of $L$. parsia, body composition, feed utilization efficiencies and percentages and survival among the experimental groups. 


\section{GROWTH AND PROXIMATE COMPOSITION OF GREY MULLET}

\section{Results}

Effect of salinity on growth, survival rate and feeding ration of L. parsia: Initial weight of L. parsia varied from 2.11 to $9.36 \mathrm{~g}$ with a mean of $4.01 \pm 0.21 \mathrm{~g}$. The final weight varied from 2.46 to $11.33 \mathrm{~g}$ with a weight of $4.72 \pm 0.24 \mathrm{~g}$. The lowest body weight was found at the length of $6.38 \mathrm{~cm}$ whereas the highest body weight was found at $9.95 \mathrm{~cm}$ body length. Highest growth was found in T2 $(0.059 \pm 0.006)$ and the lowest was found in T5 $(0.03 \pm 0.004)$ after 90 days rearing period. Similarly, the highest SGR $(1.162 \pm 0.14 \%)$ was found in T2 and the lowest was found in $\mathrm{T} 5(0.6 \mathrm{O} 5 \pm 0.10 \%$ ) (Table I). Higher FCR was $1.03 \pm 0.25 \%$ in $\mathrm{T} 5$ whereas the lower FCR was $0.69 \pm 0.06(\%)$ in T3. Survival rate were found $100 \%$ in this experiment between 0 to $20 \%$ salinity. Growth was found significantly different among the treatment of Initial weight $(\mathrm{F}$ $(4,41)=3.42, p=.017)$; final weight $\left(\mathrm{F}_{(4,41)}=4.55, p=.004\right)$ and initial length $\left(\mathrm{F}_{(4,41)}=3.42\right.$, $p=.017)$; final length $(\mathrm{F}(4,41)=3.21, p=.022)$ according to one way ANOVA. The post hoc analysis (LSD) also showed significant difference initial weight amongst all the treatments and final weight amongst the treatments except $\mathrm{T} 1$ and $\mathrm{T} 3$. There was also a statistically significant difference in initial length and final length amongst the treatment except T3 (Table I).

Length- weight relationship of $L$. parsia in different treatments. The relationship between body length and body weight of $L$. parsia was found to be linear and positive (Fig. 1). Statistically significant relation $(p<0.05)$ was round between length and weight for the control, $\mathrm{T} 2$ and T3 except T4 and T5 (Table II).

Table I. Effect of salinity on growth, survival rate and feed utilization of Liza parsia cultured in five different salinity conditions*

\begin{tabular}{lccccc}
\hline Growth parameters & T1 (0ppt) & T2 (5ppt) & T3 (10 ppt) & T4(15ppt) & T5(20ppt) \\
\hline Initial weight $(\mathrm{g})$ & $4.46 \pm 0.59^{\mathrm{a}}$ & $4.22 \pm 0.48^{\mathrm{a}}$ & $4.60 \pm 0.28^{\mathrm{a}}$ & $4.53 \pm 0.42^{\mathrm{a}}$ & $4.57 \pm 0.35^{\mathrm{a}}$ \\
Final weight $(\mathrm{g})$ & $5.72 \pm 0.59$ & $5.98 \pm 0.50$ & $5.75 \pm 0.20^{\mathrm{a}}$ & $5.65 \pm 0.42^{\mathrm{a}}$ & $5.48 \pm 0.37^{\mathrm{a}}$ \\
Initial length $(\mathrm{cm})$ & $7.622 \pm 0.26^{\mathrm{a}}$ & $6.687 \pm 0.24^{\mathrm{a}}$ & $6.694 \pm 0.22^{\mathrm{a}}$ & $6.460 \pm 0.27^{\mathrm{a}}$ & $6.439 \pm 0.23^{\mathrm{a}}$ \\
Final length $(\mathrm{cm})$ & $8.075 \pm 0.31^{\mathrm{a}}$ & $7.282 \pm 0.26^{\mathrm{a}}$ & $7.363 \pm 0.16$ & $6.828 \pm 0.3^{\mathrm{a}}$ & $6.906 \pm 0.23^{\mathrm{a}}$ \\
Weight gain $(\mathrm{g})$ & $1.16 \pm 0.23$ & $1.76 \pm 0.19$ & $1.15 \pm 0.23$ & $1.12 \pm 0.12^{\mathrm{a}}$ & $0.91 \pm 0.15$ \\
SGR(\%BW/day) & $0.829 \pm 0.10$ & $1.162 \pm 0.14$ & $0.744 \pm 0.20$ & $0.736 \pm 0.10$ & $0.605 \pm 0.15$ \\
FCR & $0.66 \pm 0.22$ & $1 \pm 0.33$ & $0.58 \pm 0.19$ & $0.66 \pm 0.22$ & $1.03 \pm 0.25$ \\
Survival rate (\%) & 100 & 100 & 100 & 100 & 100 \\
\hline
\end{tabular}

*Different superscript letters indicate significant difference among the treatments $(p<0.05)$

Table II. Statistical analysis for length-weight relationship with growth of Liza parsia

\begin{tabular}{ccccccc}
\hline & $a^{*}$ & $b$ & $r$ & $R^{2}$ & $P$ & Growth pattern \\
\hline T1 & -7.66 & 2.74 & 0.96 & 0.932 & $8.975 \mathrm{e}-11$ & + Allometric \\
T2 & -7.78 & 2.79 & 0.94 & 0.88 & $1.164 \mathrm{e}-09$ & + Allometric \\
T3 & -5.28 & 2.03 & 0.78 & 0.919 & 0.0003643 & + Allometric \\
T4 & -6.56 & 2.41 & 0.41 & 0.961 & 0.08716 & + Allometric \\
T5 & -6.69 & 2.43 & 0.29 & 0.845 & 0.2153 & + Allometric \\
\hline
\end{tabular}

*a: regression intercept; $\mathrm{b}=$ slope; $\mathrm{R}^{2}$ : coefficient of determination, 
JOYANTA BIR et al.
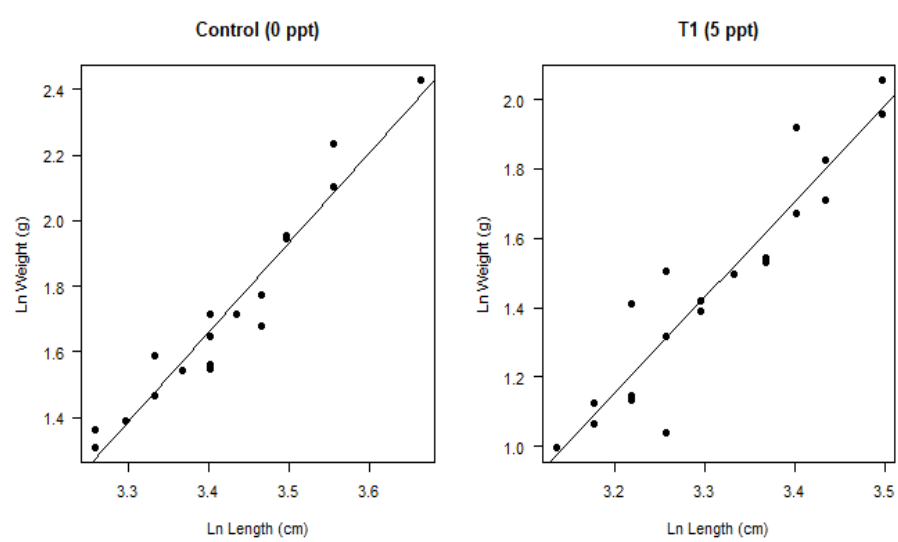

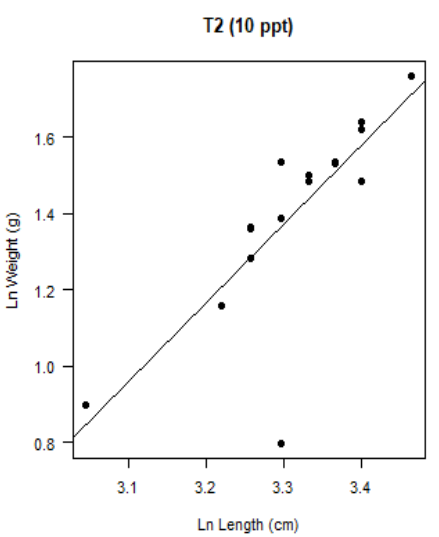

T4 (20 ppt)

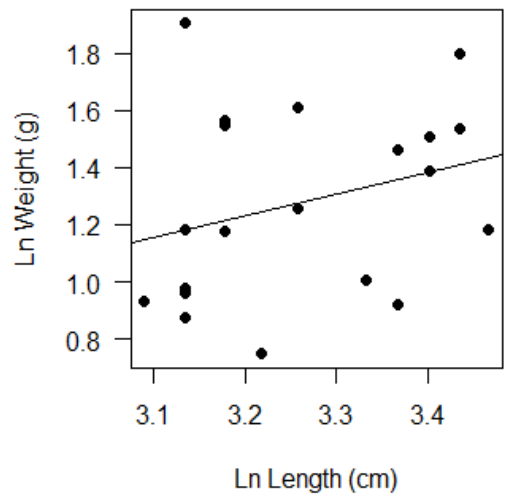

Fig. 1. Length and body weight relationships of Liza parsia at different salinities $(0,5,10,15$, and $20 \mathrm{ppt})$.

Water quality parameters. The maximum average temperature was found in the tanks of T1 $\left(29.46 \pm 1.5^{\circ} \mathrm{C}\right)$ and the minimum was found in $\mathrm{T} 4$ tanks $\left(27.98 \pm 1.0^{\circ} \mathrm{C}\right)$. The maximum DO value was found in T4 $(5.68 \pm 0.5 \mathrm{mg} / \mathrm{L})$ and the minimum DO was found in control $(5.01 \pm 0.1$ $\mathrm{mg} / \mathrm{L})$. The average $\mathrm{pH}$ value was found to be maximum in $\mathrm{T} 1(7.64 \pm 0.5)$ and minimum in $\mathrm{T} 2$ $(7.21 \pm 0.5)$. The hardness was found maximum $(237.65 \pm 7.5 \mathrm{mg} / \mathrm{L})$ in $\mathrm{T} 4$ and minimum in $\mathrm{T} 1$ $(184.55 \pm 3.5 \mathrm{mg} / \mathrm{L})$. Total ammonia nitrogen was highest in $\mathrm{T} 1(0.85 \pm 0.19)$ and lowest in $\mathrm{T} 4$ $(0.52 \pm 0.16)$ (Table III). 
GROWTH AND PROXIMATE COMPOSITION OF GREY MULLET

Table III. Mean ( \pm SD) of water quality parameters of the five treatments

\begin{tabular}{lccccc}
\hline $\begin{array}{l}\text { Water quality } \\
\text { parameters }\end{array}$ & T1 $(0 \mathrm{ppt})$ & $\mathrm{T} 2(5 \mathrm{ppt})$ & $\mathrm{T} 3(10 \mathrm{ppt})$ & $\mathrm{T} 4(15 \mathrm{ppt})$ & $\mathrm{T} 5(20 \mathrm{ppt})$ \\
\hline Temperature & $29.46 \pm 1.5$ & $28.88 \pm 1.0$ & $29.04 \pm 1.0$ & $27.98 \pm 1.0$ & $28.25 \pm 1.5$ \\
DO & $5.01 \pm 0.1$ & $5.35 \pm 0.4$ & $5.34 \pm 0.2$ & $5.68 \pm 0.5$ & $5.65 \pm 0.5$ \\
$\mathrm{pH}$ & $7.64 \pm 0.5$ & $7.21 \pm 0.5$ & $7.23 \pm 0.5$ & $7.35 \pm 0.5$ & $7.25 \pm 0.5$ \\
Hardness & $184.55 \pm 3.5$ & $212.56 \pm 5.5$ & $226.504 \pm 7.8$ & $232.77 \pm 6.5$ & $237.65 \pm 7.5$ \\
Alkalinity & $162 \pm 1.7$ & $157 \pm 0.8$ & $160 \pm 1.5$ & $155 \pm 0.5$ & $158 \pm 1.65$ \\
TAN & $0.85 \pm 0.19$ & $0.54 \pm 0.12$ & $0.8 \pm 0.1$ & $0.52 \pm 0.16$ & $0.55 \pm 0.2$ \\
\hline
\end{tabular}

Proximate composition of $L$. parsia: The protein content was highest in $\mathrm{T} 4(16.5 \pm 0.48 \%)$ and lowest in T2 $(13.365 \pm 0.445 \%)$. It was comparatively higher in higher salinities. On the contrary lipid content was highest in T4 $(9.625 \pm 0.495 \%)$ and lowest in T5 $(4.365 \pm 0.185 \%)$. The moisture content was highest in T5 $(69.415 \pm 0.835 \%)$ and lowest in T3(64.9 $\pm 0.33 \%)$. Similarly, ash content was highest in T5 $(10.465 \pm 0.135 \%)$ and lowest in T2 $(6.96 \pm 0.03 \%)$ (Table IV).

Table IV. Proximate composition of $L$. parsia fingerling cultured at different salinities

\begin{tabular}{ccccc}
\hline $\begin{array}{c}\text { Treatment } \\
\text { groups }\end{array}$ & Protein (\%) & Lipid (\%) & Moisture (\%) & Ash (\%) \\
\hline T1 (0ppt) & $13.56 \pm 0.02$ & $9.31 \pm 0.33$ & $67.55 \pm 0.48$ & $7.67 \pm 0.14$ \\
T2 (5ppt) & $13.365 \pm 0.445$ & $8.59 \pm 0.1$ & $67.24 \pm 0.34$ & $6.96 \pm 0.03$ \\
T3 (10ppt) & $16.35 \pm 0.23$ & $5.36 \pm 0.37$ & $64.9 \pm 0.33$ & $8.19 \pm 0.15$ \\
T4 (15ppt) & $16.5 \pm 0.48$ & $9.625 \pm 0.495$ & $69.24 \pm 0.26$ & $10.465 \pm 0.025$ \\
T5 (20ppt) & $16.5 \pm 0.29$ & $4.365 \pm 0.185$ & $69.415 \pm 0.835$ & $10.465 \pm 0.135$ \\
\hline
\end{tabular}

\section{Discussion}

Effect of salinity on growth, survival and feed conversion efficiency of L. parsia: Mullets are highly euryhaline and thrive in a wide range of salinities (Cardona 2006). Euryhaline fishes can perceive and compensate for large transformations in environmental salinity (Kültz 2015). Evans (1984) has estimated that $95 \%$ of teleost species are stenohaline, living entirely in either freshwater or seawater. The growth and metabolism of euryhaline species are generally affected by the salinity due to the use of the energy for osmoregulation is not available for their growth (Wootton 1992).

In the present study, best growth (weight-gain and SGR) was found in T2 (5 ppt salinity) and the lowest in T5 (at $20 \mathrm{ppt}$ salinity). Growth rates of L. parsia were relatively low but comparable to previous studies (Richard et al. 2010). In the case of Chelon parsia, the highest SGR was recorded in the fish cultured at $10 \mathrm{~g} / \mathrm{l}$ salinity, and the growth rates between freshwater and $5 \mathrm{~g} / 1$ salinity were not differed significantly $(p>0.05)$ which is less similar to the present study. Barman et al. (2012) successfully cultured flathead grey mullet (grey 
JOYANTA BIR et al.

mullet), Mugil cephalus in freshwater, and various salinities (10, 15, 20, and $25 \mathrm{~g} / \mathrm{l}$ salinity). The study revealed that SGR was significantly enhanced in fish maintained at $10 \mathrm{~g} / \mathrm{l}$ salinity (SGR $4.70 \%$ ) in comparison with freshwater (SGR $3.12 \%$ ). Again, Biswas et al. (2017) evaluated growth performances of Mugil cephalus fingerlings in brackish water ponds at Sundarbans (11-12 g/l salinity) under different management system and found satisfactory growth rates (SGR ranged from 1.22 to $1.78 \%$ ) which was more or less similar to the present study. For Mugil liza final body weight and SGR were significantly affected by water salinity. They increased with increasing salinity, being significantly higher in salinity $24 \%$ than in freshwater $(p<0.05)$ (Lisboa et al. 2015). In the present study, the highest FCR in T5 $(1.03 \pm 0.29)$ indicates that $20 \mathrm{ppt}$ need more amount of feed per gram weight gain than others. The lowest FCR was found in T3 $(0.69 \pm 0.19)$ which indicates that feed was utilized more efficiently in T3 compared to other experimental groups which were more or less similar to the Paulraj and Kiron (1988) where they found good conversion ratios in the descending order are $25,15,20,10$ and 5 ppt. Survival rate was found $100 \%$ in this experiment between 0 to $20 \%$ salinity and these results support the findings of Paulraj and Kiron (1988) where they found no significant differences in survival rates between salinities 5 and $25 \%$. In the case of Mugil liza there was no effect of water salinity on fish survival, which was close to $100 \%$ in all treatments $(p>0.05)$ (Lisboa et al., 2015).

Water quality parameters: Recorded water quality parameters in the present study were within optimum ranges for brackish water aquaculture (Chakraborti et al. 2002). During the experimental period, the overall temperature was found from 28.0 to $30.6{ }^{\circ} \mathrm{C}$. Dissolved Oxygen (DO) is the most significant physical issue for all aquatic organisms including fish. Overall DO was 4.0 to $5.87 \mathrm{mg} / \mathrm{L}$ throughout the experiment and that was suitable for culture which was less similar to the findings of (Mondal et al. 2016) who reported that DO was almost similar throughout the culture period and ranged between 5.81 to $9.00 \mathrm{ppm}$. Chakraborti et al. (2002) according to the dissolved oxygen content of water starting from $6.7-8.3 \mathrm{mg} / \mathrm{L}$ was a satisfactory level for fish production. The $\mathrm{pH}$ range were also suitable throughout the culture period and these results almost support the findings of (Mondal et al. 2016) who observed that $\mathrm{pH}$ value was almost similar throughout the culture period and ranged between 7.92 to 8.72 . The hardness in the present study ranged between $184.55 \mathrm{mg} / \mathrm{L}$ and $237.65 \mathrm{mg} / \mathrm{L}$. Hardness values less than 20ppm may cause stress, $75-150 \mathrm{ppm}$ is suitable for fish culture and $>300 \mathrm{ppm}$ is lethal to fish life as it increases $\mathrm{pH}$, resulting in non-availability of nutrients with some euryhaline species, however, may have high tolerance limits to hardness (Bhatnagar and Devi 2013).

Length-weight relationship of L. parsia in different treatments: In the present study, it was observed that the value of the total length when plotted against the corresponding weight of fishes and the regression line drawn showed a linear and positive relationship. The isometric exponent $(b<3)$ of the length-weight relationship (LWR) in this study indicates the negative allometric growth of $L$. parisa. Wootton (1992) provides a rough idea of this situation, indicating that allometriç growth is negative $(b<3)$ if the fish gets relatively thinner as it grows larger. Mondal et al. (2016) found that the negative allometric growth of tade mullet (Liza tade) shows a shortage of food in the farming system as competition for space is not likely in such low density and low production systems. In the present study, the result also supports the findings of Mondal et al. (2016) accordingly. Relative condition factor was found to be the highest in all 


\section{GROWTH AND PROXIMATE COMPOSITION OF GREY MULLET}

groups at $18 \%$ salinity level. In the present study author found the maximum value $\left(\mathrm{r}^{2}=0.961\right)$ in T4 (salinity $15 \mathrm{ppt}$ ).

Proximate composition: The fat and energy contents of the tissue gradually increased with the increase in the salinity, showing significantly higher values at T4 (15 ppt) (Kumar et al. 2016). The present study showed that the maximum protein found in T4 (15 ppt) was almost similar to the findings of De Silva and Perera (1976), who recorded the highest protein level in $20 \mathrm{ppt}$ salinity follow by $15 \mathrm{ppt}$ and $30 \mathrm{ppt}$ in Mugil cephalus. Maceina and Shireman (1979) reported that the grass carp fingerlings experienced a comparable reduction from 80 to $76.6 \%$ in moisture content when transferred from freshwater to $12 \mathrm{ppt}$ salinity. That indicates the decrease of moisture content with increasing salinity. But in the present study is showed that the moisture content is decreasing with increasing salinity up to 10 ppt and after that increases for 15 and 20 ppt. In another study conducted by Barman et al. (2012), on milk fish body composition, showed that there is a significant reduction in the level of moisture from $79.93 \pm 0.01$ to $78.47 \pm 0.01$ with the increase of salinity up to $15 \mathrm{ppt}$.

Conclusions: Salinity is clearly a crucial factor that directly affects the growth and body composition of $L$. parsia. As being a euryhaline species $L$. parsia can survive in a wide range of salinity level that has already been proven through our experiment. However, their better growth performance shown at 5 ppt which is very common salinity ranges in coastal area of Bangladesh. On the other hand, increasing salinity doesn't hamper the biochemical composition of the fishes.

Because of delicious taste and nutritious value this species has huge public demand and having reasonable market price. In this context, this species can be introduced as a potential aquaculture species in these salinities intruded coastal region of Bangladesh.

Acknowledgements: The authors would like to acknowledge the Ministry of Education, Bangladesh for the 'Grants for Advanced Studies in Science' to carry out this research work. The authors also gratefully acknowledge the Ministry of Science and Technology, Bangladesh for providing National Science and Technology (NST) fellowship to the first author of this paper.

\section{Literature Cited}

Alam, M.Z., L.C. Boggs, S. Mitra., M. Haque, J. Halsey, M. Rokonuzzaman, B. Saha and M. Moniruzzaman, 2017. Effect of salinity intrusion on food crops, livestock, and fish Species at Kalapara coastal belt in Bangladesh. J. Food Qual., 2017: 2045157.

Azad, M.A.K., S.S. Islam, I.N. Sithi, A.K. Ghosh, G.R. Banu, J. Bir and K.A. Huq, 2019. Effect of probiotics on immune competence of giant freshwater prawn Macrobrachium rosenbergii. Aquac. Res., 50 (2): 644-57.

Barman, U.K., S.K. Garg and A. Bhatnagar, 2012. Effect of different salinity and ration levels on growth performance and nutritive physiology of milkfish, Chanos chanos (Forsskal)Field and laboratory Ssudies. Fish Aquac J.,:1-12

Bhatnagar, A. and P. Devi, 2013. Water quality guidelines for the management of pond fishcCulture. Int. J. Environ. Sci., 3(6): 1980-2009.

Bir, J., B.M.S. Rahman, M.S.-E-Mahfuj, M.A. Rahman and M.S. Shah, 2016. Reproductive biology and feeding habit of Gold Spot Mullet, Liza parsia.Am. J. Zool. Res., 4 (1): 7-12.

Biswas, G., J. K. Sundaray, S.B. Bhattacharyya, P.S.S. Anand, T.K. Ghoshal, D. De, P. Kumar, K. Sukumaran, A. Bera and B. Mandal, 2017. Influence of feeding, periphyton and 
JOYANTA BIR et al.

compost application on the performances of Striped Grey Mullet (Mugil Cephalus L.) fingerlings in fertilized brackishwater ponds. Aquaculture, 481: 64-71.

Cardona, L., 2006. Habitat selection by Grey Mullets (Osteichthyes: Mugilidae) in Mediterranean estuaries: The role of salinity. Sci. Mar., 70 (3): 443-55.

Chakraborti, R.K., J.K. Sundaray and T.K. Ghoshal, 2002. Production of Penaeus monodon in the tide fed ponds of Sunderbans. J. Sea Res., 42: 157-68.

Dayal, J. Syama., K. Ambasankar, R. Jannathulla, K.P. Kumaraguruvasagam, M. Kailasam and K.K. Vijayan, 2017. Polyculture of Mullets in brackishwater using compounded feed: Proximate and mineral profiles in comparison with wild mullets. Indian J. Fish., 64: 50-57.

De Silva, S.S. and P.A.B. Perera, 1976. Studies on the young grey mullet, Mugil cephalus L.: I. Effects of salinity on food intake, growth and food conversion. Aquaculture, 7 (4): 327 38.

DoF, 2018. Yearbook of Fisheries Statistics of Bangladesh, 2017-18. Fish Resour Survey System (FRSS), Dept. of Fisheries Bangladesh. 35: 129. http://www.fisheries.gov.bd.

Evans, D.H., 1984. The roles of gill permeability and transport mechanisms ineEuryhalinity. In Fish Physiology, X:239-83. Elsevier.

Ghosh, A.K., J. Bir, M.A.K. Azad, A.F.M. Hasanuzzaman, M.S. Islam and K.A. Huq, 2016. Impact of commercial probiotics application on growth and production of giant freshwater prawn (Macrobrachium Rosenbergii De Man, 1879). Aquac. Rep., 4: 112-17.

Islam, M.S., N. Begum and S.L. Rahman, 2017. Culture potentials of green back mullet, Chelon subviridis (Parse) under different stocking densities in south-western region of Bangladesh. Int. J. Fish. Aquat. Stud., 5 (2): 533-37.

Kültz, D., 2015. Physiological mechanisms used by fish to cope with salinity stress.J. Exp. Biol., 218 (12): 1907-14.

Kumar, A., V.H. Krishna, A.K. Reddy, N.K. Chadha and A.M.B. Rani, 2016. Effect of salinity on proximate composition of Pangasianodon hypophthalmusreared in inland saline water. Int. J. Zool. Stud., 3: 19-21.

Lim, P.Y., 1987. Fish protein extractability and its determination. In: Laboratory manual on analytical methods and procedures for fish and fish products. (Hasegawa, H. ed.) p. A5.1A5.3. Singapore: Marine Fisheries Development SAFDEC.

Lisboa, V., I.F. Barcarolli, L.A. Sampaio and A. Bianchini, 2015. Effect of salinity on survival, growth and biochemical parameters in juvenile lebranch mullet Mugil liza (Perciformes: Mugilidae). Neotrop. Ichthyol., 13 (2): 447-52.

Maceina, M. J. and J. V. Shireman, 1979. Grass carp: effects of salinity on survival, weight loss, and muscle tissue water content. Prog. Fish-Cult., 41 (2): 69-73.

Mahmuduzzaman, M., Z.U. Ahmed, A.K.M. Nuruzzaman and F.R.S. Ahmed, 2014. Causes of salinity intrusion in coastal belt of Bangladesh. Int. J. Plant. Res., 4 (4A): 8-13.

Mondal, A., S.B. Bhattacharyya, S. Mandal, S. Purkait, D. Chakravartty and A. Mitra, 2016. Growth performances, feeding ecology and prey preferences of tade mullet, Liza tade (Forsskål, 1775) in extensive brackishwater farming system. Int. J. Fish. Aquat. Stud., 4 (3): 436-43.

Panda, D., S.K. Mohanty, A.K. Pattnaik, S. Das and S.K. Karna, 2018. Growth, mortality and stock status of mullets (Mugilidae) in Chilika Lake, India. Lakes Reserv. Res. Manag., 23 (1): 4-16.

Paulraj, R. and V. Kiron, 1988. Influence of salinity on the growth and feed utilization in Liza parsiafry. In. M. Mohan Joseph (ed.) the First Indian Fisheries Forum Proceedings, 61-63. 


\section{GROWTH AND PROXIMATE COMPOSITION OF GREY MULLET}

Indian Branch, Mangalore: Asian Fisheries Society.

Rabbani, G., S. Munira and S. Saif, 2018. Coastal community adaptation to climate changeInduced salinity intrusion in Bangladesh. In Agril. Econ.-Current Issues. Intech Open.

Richard, M., J-T. Maurice, A. Anginot, F. Paticat, M.C.J. Verdegem and J.M.E. Hussenot, 2010. Influence of periphyton substrates and rearing density on Liza aurata growth and production in marine nursery ponds. Aquaculture, 310 (1-2): 106-11.

Trivedi, S., S. Chakraborty, S. Zaman, P. Pramanick, P. Fazli, G. Amin and A. Mitra, 2015. Impact of salinity on the condition factor of commercially important fin fish in the lower Gangetic delta. J. Environ. Sci. Computer Sci. Eng. Technol., 4 (2): 473-80.

Wootton, R.J., 1992. Fish Ecology Tertiary Level Biology. Blackie London 212. Link: Https://Goo. GI/Qj619J.

(Manuscript received 27 August 2020) 